\title{
YogaSmart cities: A mission for health
}

\author{
Sanjay Kalra, Sumedha Kataria ${ }^{1}$, AK Pandey ${ }^{2}$, Rajiv Girdhar ${ }^{3}$, Asim Das ${ }^{4}$, Naresh Kardwal ${ }^{5}$ \\ Department of Endocrinology, Bharti Hospital, Karnal, India, ${ }^{1}$ Municipal Commisioner, Karnal, ${ }^{2}$ Department of Physiology, ESIC Medical \\ College, Faridabad, ${ }^{3}$ Department of Waste Disposal, Municipal Corporation, Karnal, ${ }^{4}$ Dean, ESIC Medical College, Faridabad, ${ }^{5}$ Medical Officer, \\ Civil Surgeon Office, Karnal, India
}

\section{INTRODUCTION}

India's Smart City Mission has selected 100 urban bodies, which have been designated as smart cities. ${ }^{[1]}$ While the definition of smart cities is not standardized, and is open to debate, all smart cities share certain features. The Ministry of Urban Development lists these characteristics, which include "health and education."[2]

Smart cities should have smart citizens, smart citizens are healthy citizens, and healthy citizens are happy citizens. To achieve this optimal state, the concept of HeartSmart and SugarSmart cities has been proposed. ${ }^{[3]}$

We suggest the concept of YogaSmart cities, as a means of ensuring happy, healthy, and smart citizenry, who can contribute to the growth and development of smart cities (and nations). A YogaSmart city is one which encourages and facilitates the practice of yoga by ensuring availability, affordability, and accessibility of the required institutional, physical, social, and economic infrastructure, and utilizes the full potential of yoga through smart solutions.

Yoga, derived from the Sanskrit word "Yuj," means the union of the body, breath, and mind. Yoga, as a way of life, constitutes asanas, regulated breathing (pranayama), and awareness of yoga sutras (principles) that govern the mind ${ }^{[4]}$ Yoga, by acting through various biological

\begin{tabular}{|l|l|}
\hline \multicolumn{2}{|c|}{ Access this article online } \\
\hline Quick Response Code: & Website: \\
& www.joshd.net \\
\hline & \\
\hline
\end{tabular}

pathways ${ }^{[5]}$ helps mitigate the risk factors which cause noncommunicable diseases (NCDs). Regular practice of yoga enhances awareness of mind and body ${ }^{[6]}$ and promotes self-discipline.

Yoga has been suggested as a low-cost adjunct therapy for obesity ${ }^{[7]}$ and also as an endocrine therapy ${ }^{[8]}$ To achieve its full promotive and preventive potential in urban dwellers, yoga needs support that smart cities can provide.

Institutional support is provided at the national level, as the Prime Minister has endorsed the \#yogafightsdiabetes campaign. ${ }^{[9]}$ The medical profession, too, has a role to play in creating the institutional infrastructure. The Employees State Insurance Medical College, Faridabad, has begun a Yoga Research Laboratory, under the aegis of the Department of Physiology. This lab will focus on the role of yoga in NCDs.

Physical infrastructure can be provided at a low cost by allocating centrally located areas and indoor halls for yoga sessions across the city. Existing grounds and buildings can be used for this purpose during the early morning, pre-office hours. In Karnal, for example, citywide yoga enthusiasts, led by Jaswant Rai Kalra and Dinesh Gulati, use open grounds near the MiniSecretariat for well-attended morning yoga sessions.

This is an open access article distributed under the terms of the Creative Commons Attribution-NonCommercial-ShareAlike 3.0 License, which allows others to remix, tweak, and build upon the work non-commercially, as long as the author is credited and the new creations are licensed under the identical terms.

For reprints contact: reprints@medknow.com

How to cite this article: Kalra S, Kataria S, Pandey AK, Girdhar R, Das A, Kardwal N. YogaSmart cities: A mission for health. J Soc Health Diabetes 2016;4:55-6.

Corresponding Author: Dr. Sanjay Kalra, Department of Endocrinology, Bharti Hospital, Karnal - 132 001, Haryana, India. E-mail: brideknl@gmail.com 
Social infrastructure or social endorsement is important in creating YogaSmart cities. Acceptance and endorsement of yoga, as a means of promotive, preventive, and supplement to curative health care, is necessary. Such a situation is created by social marketing, which highlights the benefits of yoga among all stakeholders. Apart from the government, nongovernmental organizations such as resident welfare associations, faith-based groups, youth clubs, women's associations, and professional guilds can support this cause.

Minimal economic infrastructure is required for the practice of yoga. On the contrary, yoga can kick-start and stimulate a health and wellness industry, which can help provide economic smartness to YogaSmart cities. A market for ancillary supplies such as yoga mats, pillows, costumes, and informational books/compact disks can also be created.

Use of "smart solutions" is considered an attribute of smart cities. Such solutions encompass a wide variety of fields. Yoga can be used as a supplementary nonpharmacological therapy for many musculoskeletal conditions and NCDs. ${ }^{[5,8,10,11]}$ This can be promoted as a part of e-health or mobile health campaigns. Smart health status can be achieved by preparing person-centered applications which recommend useful yoga asanas (and mention contraindicated asanas) upon entry of the basic clinical data, including age, gender, and presence or absence of comorbid conditions. Smart technology can also be used to map the distribution of NCDs in a particular city so that yoga services can be provided in high-risk areas. Similar mapping can be done to ensure adequate provision in high-demand localities.

Creating a YogaSmart identity will help further the socioeconomic development of the city. Yoga helps individuals enjoy comprehensive health (as defined by the World Health Organization), and also improves their productivity, leading to enhanced growth of the city. By assisting in brand building, it also encourages health and medical tourism, which supports local business and brings in much-needed revenue.

Creation of YogaSmart cities should prove to have a beneficial effect on the control of NCDs, including obesity, diabetes, and cardiovascular disease, while benefiting the city as well.

Financial support and sponsorship

Nil.

Conflicts of interest

There are no conflicts of interest.

\section{REFERENCES}

1. Coverage and Duration. Available from: http://www.smartcities.gov. in/SmartCitiesPPT/Slide1.JPG. [Last accessed on 2016 Jun 26].

2. Smart City Guidelines. Available from: http://www.smartcities. gov.in/writereaddata/SmartCityGuidelines.pdf. [Last accessed on 2016 Jun 26].

3. Kalra S, Kataria S, Pandey AK, Girdhar R, Das A, Kardwal N. Sugar Smart, Heart Smart: The way Smart Cities should be. J Soc Health Diabetes 2016;7: 50-1.

4. Shankar HH. Patanjali Yog Sutras - A commentary, Vol 1. $1^{\text {st }}$ ed. Bangalore: Sri Sri Publication Trust. 2011.

5. Jyotsna VP. Prediabetes and type 2 diabetes mellitus: Evidence for effect of yoga. Indian J Endocrinol Metab 2014;18:745-9.

6. Zope SA, Zope RA. Sudarshan kriya yoga: Breathing for health. Int J Yoga 2013;6:4-10.

7. Aswathy S, Unnikrishnan AG, Kalra S. Effective management of type 2 DM in India: Looking at low-cost adjunctive therapy. Indian J Endocrinol Metab 2013;17:149-52.

8. Kaduskar P, Suryanarayana KM. Yoga: An endocrine therapy. Indian J Endocrinol Metab 2015;19:437-8.

9. Text of PM's "Mann ki Baat" Programme on All India Radio on; 26 June, 2016. Available from: http://www.pib.nic.in/newsite/ PrintRelease.aspx?relid = 146513. [Last accessed on 2016 Jun 26].

10. Jain S. Effect of 6 weeks pranava yoga training on cardiovascular parameters in prehypertensive young adults. Hypertension 2016;8:10.

11. Cheung C, Wyman JF, Savik K. Adherence to a yoga program in older women with knee osteoarthritis. J Aging Phys Act 2016;24:181-8. 